EVS25

Shenzhen, China, Nov 5-9, 2010

\title{
Trends and insight in heavy-duty vehicle electrification
}

\author{
Carlo $\mathrm{Mol}^{1}$, Michael O'Keefe ${ }^{2}$, Arie Brouwer ${ }^{3}$ and Jussi Suomela ${ }^{4}$ \\ ${ }^{1}$ VITO (Flemish Institute for Technological Research), Boeretang 200, Mol, 2400, Belgium, carlo.mol@vito.be \\ ${ }^{2}$ National Renewable Energy Laboratory, 1617 Cole Blvd., Golden, Colorado, USA, michael.okeefe@nrel.gov \\ ${ }^{3}$ NL Agency, Postbox 8242,3503 RE Utrecht, The Netherlands, dick.appels@agentschapnl.nl \\ ${ }^{4}$ Aalto University, Postbox 15500,FI-00076, Aalto, Finland, jussi.suomela@aalto.fi
}

\begin{abstract}
This paper describes the results from Annex XII "Heavy-duty hybrid vehicles" of the International Energy Agency (IEA) Implementing Agreement on "Hybrid and Electric Vehicles" (IA-HEV). Since 1993, this Implementing Agreement has provided a platform to exchange knowledge, experience and strategies among the member states on the latest developments in hybrid and electric vehicles, mostly passenger cars. Because heavy-duty vehicles have specific technical requirements and economic boundary conditions compared to the passenger car market, a dedicated Annex was started in 2007 and has run for several years until the end of 2010. Six countries (Belgium, Canada, Finland, Switzerland, the Netherlands and the United States) have been participating to collect and share relevant information on the latest technical and market developments in "electrified" trucks, buses and mobile work machines. This information will broaden the insight in the existing applications of heavy-duty vehicles electrification and can provide essential information for future heavy-duty hybrid vehicle deployment projects.
\end{abstract}

Keyword: Heavy-duty hybrid vehicles, Vehicle electrification, Trucks, Buses, Mobile Work Machines

\section{Introduction Annex XII "Heavy-duty Hybrid Vehicles"}

Since 1993, the Implementing Agreement "Hybrid \& Electric Vehicles" (IA HEV) of the International Energy Agency (IEA) has provided a platform to exchange knowledge, experience and strategies among the governments of the member states. Special working groups called "Annexes" conduct investigations concerning technologies, applications, markets and environmental issues. The variety of topics addressed by the Annexes mirror the worldwide development of vehicles with electric and hybrid propulsion systems.
Heavy-duty vehicles encompass a wide diversity of applications and have specific technical requirements and economic boundary conditions compared to the passenger car market. Therefore, a specific Annex focusing on "heavy-duty hybrid vehicles" was started in 2007. In Annex XII, six countries (Belgium, Canada, Finland, Switzerland, the Netherlands and the United States) are participating to collect and share relevant information on the latest technical and market developments. To collect and organize all required information, three subtasks have been defined.

The first subtask is technology oriented and aims at structuring the information on heavy-duty hybrid vehicle components, systems and 
configurations. This subtask identifies and illustrates the technical requirements, especially highlighting where they are different from lightduty requirements, the available technologies and their characteristics, and the system integration requirements. Additionally, there is a focus on powertrain configurations (topologies) and powertrain strategies for high efficiency and low emissions.

The second subtask is market oriented and targets collecting market information on heavy-duty hybrid vehicles. The current market of existing hybrid prototypes and standard vehicles needs to be investigated. This subtask will increase the insights into the applications where heavy-duty hybrids have been an effective solution and can thus provide essential information for future hybrid vehicle deployment projects. To address the potential of heavy-duty hybrid vehicles it is useful to identify niche applications that may benefit to a great extent from hybridization.

The third subtask is dissemination oriented and involves collecting and disseminating general information and promoting the Annex XII objectives and results to a broad range of stakeholders. This can be done by setting up a dedicated website, preparing papers, giving presentations at relevant conferences, and keeping up contact with relevant stakeholders through the sharing of information on heavy-duty hybrid developments.

\section{Classification}

A classification of heavy-duty hybrid vehicles according to purpose or operational application has been agreed upon to focus the study of Annex XII and to pose fewer difficulties in combining the vehicles of Europe and the USA. Table 1 shows the main categories. See $\S 4.1$ for a table that compares the trucks classification in the US with Europe.

Table 1: Classification heavy duty vehicles Annex XII

\begin{tabular}{|c|c|}
\hline Main & Sub categories \\
\hline Bus & $\begin{array}{ll}\text { - } & \text { City } \\
\text { - } & \text { regional } \\
\text { - } & \text { long distance }\end{array}$ \\
\hline Truck & $\begin{array}{ll}\text { - } & \text { city distribution/delivery } \\
\text { truck } \\
\text { - } & \text { regional distribution } \\
\text { - } & \text { inter- and national transport }\end{array}$ \\
\hline
\end{tabular}

\begin{tabular}{|c|c|}
\hline $\begin{array}{l}\text { Mobile work } \\
\text { machines }\end{array}$ & $\begin{array}{l}\text { - construction, mining, and } \\
\text { earth moving: loaders, } \\
\text { excavators, dumpers, } \\
\text { bulldozers, etc. } \\
\text { - } \text { agriculture and forestry: } \\
\text { tractors and their } \\
\text { accessories, harvesters, } \\
\text { forwarders, etc. } \\
\text { transportation of goods and } \\
\text { material handling: forklifts, } \\
\text { straddle carriers, Rubber } \\
\text { Tyred Gantry cranes, } \\
\text { terminal tractors, etc. } \\
\text { municipal or janitorial } \\
\text { machines: gardening, } \\
\text { cleaning, etc. }\end{array}$ \\
\hline
\end{tabular}

\section{Technology overview}

There are many different types of advanced technology power trains. Some of the major types are all-electric, hybrid electric, plug-in hybrid electric, and hydraulic hybrid power trains. According to the 2008 Vehicle Technologies Market Report issued by the U.S. Department of Energy [1], the first diesel-electric hybrid in the United States was produced in 2007. As of July 2009, approximately 1000 units have been sold around the world. The incremental price of these diesel hybrid electric medium-size trucks ranged from $\$ 45,000$ to $\$ 60,000$ (U.S. dollars) in 2008 .

\subsection{All-Electric Powertrains}

In an all-electric powertrain, an electrical energy storage system such as a battery pack provides power to an electric traction drive to move the vehicle and power accessory loads. System components include the energy storage unit, which stores electrical energy; an inverter for power conversion between the battery and the electric motor; a converter to condition the power sent to low-voltage accessory loads; power electronics, for charging the energy storage system; an electric motor for traction power, and other components for energy recovery of kinetic energy and regenerative breaking. Electric powertrain gain increased efficiency by using more efficient electric motors, recovery of kinetic energy, no idle losses. There are no local emissions from the electric vehicle. The 
greenhouse gas emissions depend on the mix of fuels used by the electric power plant.

Vendors of vehicles with all-electric powertrain systems include Modec, Optare and Smith Electric.

\subsection{Hybrid Electric Powertrains}

Hybrid powertrain systems use two sources of power to propel the vehicle. The hybrid system uses the advantages of the two power sources to attain lower fuel consumption. Typically, the two power sources are a petroleum-fueled internal combustion engine and an electric motor with battery system. Systems that combine a petroleum-fueled internal combustion engine with hydraulic accumulators also exist (see \$3.4).

Hybrid powertrains gain increased efficiency through the following mechanisms:

- $\quad$ Unloading harsh transient operations (e.g., launch acceleration and passing maneuvers) from the internal combustion engine

- Augmenting the engine torque for transient maneuvers (e.g., short accelerations) with the secondary power system, which allows designers to downsize the internal combustion engine so it can operate at higher average loading and higher average efficiency

- Recapturing a portion of the vehicle's kinetic energy during deceleration, which is known as regenerative braking

- Meeting the accessory (or auxiliary) power demand when stopped by using the secondary power system, which allows the internal combustion engine to turn off.

The majority of advanced technology powertrain systems in commercial use are hybrid systems and the majority of those are hybrid electric. There are three major hybrid vehicle configuration subtypes: series hybrids, parallel hybrids, and series/parallel or power-split hybrids. The power-split systems can be further subdivided into input power-split and compound power-split systems as shown in Fig. 1. The major differences between these subtypes relates to how energy flows from the power sources to the wheels. In a series hybrid, energy flows from one power source through all of the components in series (that is, one after another). In a parallel hybrid, each of the on-board power sources can provide energy directly to the wheels. A series/parallel or power-split hybrid can take on aspects of both the series and parallel system. Although hybrids are normally discussed in the context of hybrid electric vehicles (HEVs), the same designations described above can be used for other hybrid systems, such as hydraulic hybrids.

The primary power source in a hybrid electric system - whether it is a series, parallel, or powersplit system-is almost always an internal combustion engine, although other options such as fuel cells or gas micro-turbines have been used in transit buses.

The secondary power source is typically an electric motor connected to a battery system. Lead acid batteries have been used in the past, although more recent hybrids use nickel metal hydride battery chemistry. Lithium ion chemistries are anticipated for future systems. Ultracapacitors have been used successfully in some hybrid applications, as well. Although ultracapacitor systems do not have high energy density, they are ideally suited for some hybrid applications. For example, they have been successfully demonstrated in refuse hauling applications in the United States [2].

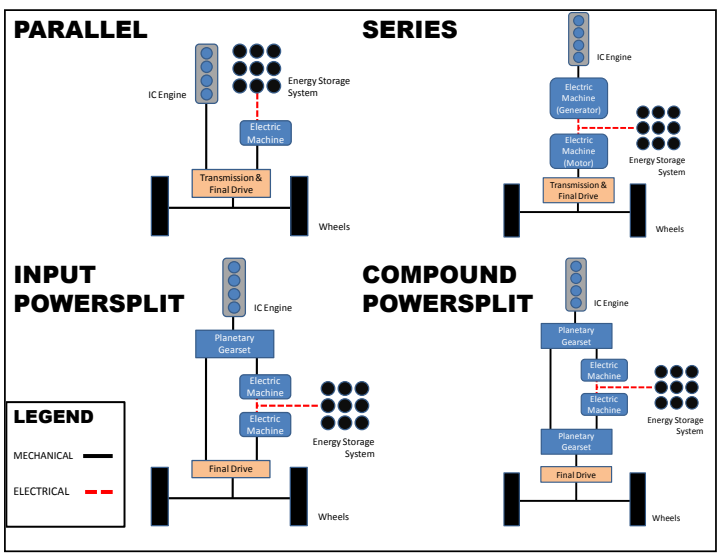

Figure 1: Types of Hybrid Electric Powertrain Systems

One advantage of a hybrid electric system is its ability to provide electric power to off-vehicle electrical equipment-effectively working as a separate generator unit. This capability is of interest to military and commercial buyers. The benefit of off-vehicle power was demonstrated by powering water pumps as part of the Hurricane Katrina relief effort in New Orleans, Louisiana, in 2005 [3]. 
Vendors of heavy hybrid electric vehicles and/or major hybrid powertrain components include Oshkosh Truck Corporation, International Truck, Eaton Transmission, BAE Systems, ISE Research, Azure Dynamics, Volvo Truck, Van Hool, VDL Jonckheere, Kabus, etc. Vocations for heavy-duty hybrid electric vehicles include package delivery, refuse hauling, inner-city delivery, transit bus, and utility trucks. Several experience reports are available to give insight into the performance of hybrid electric vehicles systems. A selection of these reports is discussed below.

Data from fleet tests of the Orion Transit Bus using the BAE Systems HybriDrive, a series hybrid electric powertrain, is available from several reports $[4,5]$. In one study, over the 12 month period the hybrid transit buses were studied, a $34 \%$ to $40 \%$ higher fuel economy was demonstrated by the hybrid buses over the baseline diesel units operating under similar driving conditions in the New York City Transit bus fleet [5].

In a study by Lammert [6], six model year 2007 Freightliner $\mathrm{P} 70 \mathrm{H}$ hybrid delivery trucks were compared to the equivalent model year 2006 Freightliner P70D diesel baseline trucks in a UPS fleet. The hybrid powertrain for the $\mathrm{P} 70 \mathrm{H}$ is a parallel hybrid system with 6 speed automated manual transmission made by Eaton Corporation. The diesel internal combustion engine for the $\mathrm{P} 70 \mathrm{H}$ is does not take advantage of engine downsizing and is the same size, make, and model as that of the P70D. Additionally, a P100H hybrid truck was tested and compared with a P100D diesel baseline truck at the National Renewable Energy Laboratory's Renewable Fuels and Lubricants (ReFUEL) laboratory heavy duty chassis dynamometer. On-road results indicated an average of $28.9 \%$ greater fuel economy for the hybrid vehicles over the baseline diesel vehicles. Chassis dynamometer tests indicated 31 to $37 \%$ better fuel economy for the hybrid system over the diesel baseline for the driving profiles considered. A picture of the chassis dynamometer test conducted at NREL appears in Fig. 2.

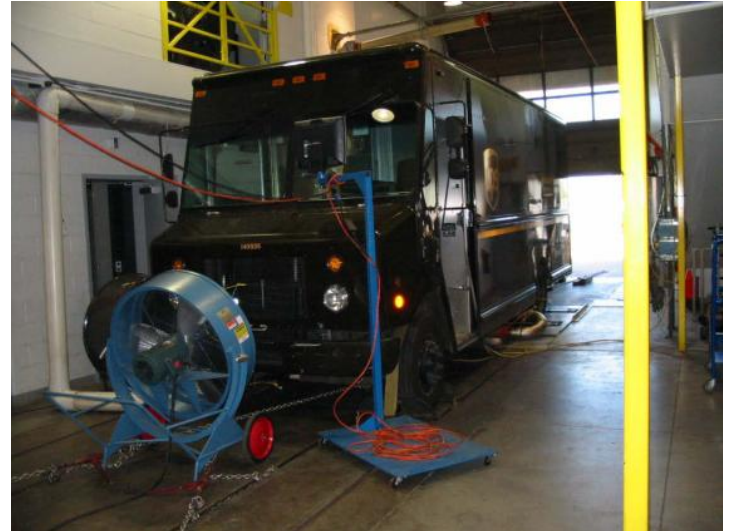

Figure 2: UPS Freightliner P100H with Eaton Hybrid Electric System tested at NREL's ReFUEL Laboratory

A study by Hayes et al. [7] investigated the compound powersplit hybrid system used in a 2004 New Flyer bus powered by an Allison EP50 system. The hybrid fuel economy benefit was found to vary from 30.3 to $74.6 \%$ depending on the test cycle used for evaluation.

\subsection{Plug-in Hybrid Electric Powertrains}

A plug-in hybrid electric vehicle is a cross between a full-electric vehicle and a hybrid electric vehicle. The vehicle is meant to operate substantially on electric power with an internal combustion engine (or other prime mover) powered generator set available to provide peak power capability and range extension. The electricity to charge the battery comes from the electric utility grid-ideally from charging overnight when electric demand is low.

For passenger cars which are typically parked most of their lifetime and only occasionally taken on long trips, the PHEV powertrain is believed to be a good fit. For heavy vehicles, not all vocations may be commercially viable for a PHEV power train. One vocation that is being developed for commercial truck PHEVs is that of the utility bucket truck or aerial lift truck $[8,20]$. Conventional utility bucket trucks currently require an idling engine to power the vehicle's hydraulic lift bucket. The PHEV power train would allow this energy to be supplied electrically through on-board electric energy storage, thus saving fuel, lowering emissions, and reducing noise [9]. 


\subsection{Hydraulic Hybrid Powertrains}

Hydraulic hybrid systems are available in both series and parallel configurations. The hydraulic hybrid system uses a reservoir of hydraulic fluid, a high pressure accumulator, and a sophisticated hydraulic pump. Energy from the driveline captured from regenerative braking, for example, can be stored by pumping hydraulic fluid from the reservoir into the high-pressure accumulator where typically an inert gas such as Nitrogen is compressed. By releasing the pressure from the high-pressure accumulator, hydraulic fluid flows from the accumulator back into the reservoir through the pump system and can provide torque to the driveline for acceleration events. Vendors of hydraulic hybrid powertrains include Eaton Transmission [10] and Bosch Rexroth [11].

\section{$4 \quad$ Market overview}

Transportation of goods is a basic economic activity of the logistical chain from source of materials to production of end products and from place of production to place of consumption. Transportation of persons or a group of persons is part of the public transportation system in a city, region or country. These activities of transportation are part of the total industrial and economic system in a country. In this study of the IEA/IA-HEV the focus will be on road transportation and particularly on the application of heavy duty vehicles.

Commercial goods vehicles in Europe have been classified as follows:

- $\quad$ LCV / LDV - Light Commercial / Duty Vehicle, any vehicle up to and including $3.5 \mathrm{t} \mathrm{GVW}^{1}$

- $\quad$ HGV - Heavy Goods Vehicle, goods transport vehicles with $>3.5 \mathrm{t} \mathrm{GVW}$

HGVs can also be segmented into:

- $\quad$ MDV: Medium Duty Vehicle, 3.5-15t GVW, including both rigid and drawbar trailer vehicles.Vehicles in this segment tend to be predominantly used as delivery vehicles with majority urban driving and frequent start/stop activity.

- HDV: Heavy Duty Vehicle, $>15 t$ GVW, including both rigid and articulated vehicles.Vehicles in this segment tend to be used for regional and long haul distribution with largely continuous high speed driving and infrequent start/stop activity.

In the USA commercial goods vehicles are classified according to the class categories, class 3 up to class 8 [12]. MDVs are considered to be class 4,5 and 6 . HDVs are considered to be class 7 and 8 .

\subsection{Vehicle Applications}

In Table 2, an overview is presented about vehicle category, application and regional characteristics. This table shows some of the differences in the used vehicles in any application in a category.

Table 2: Heavy Duty Vehicle Categories and Applications

\begin{tabular}{|c|c|c|c|}
\hline Application & $\begin{array}{l}\text { North } \\
\text { Americas }\end{array}$ & Europe & Asia \\
\hline \multicolumn{4}{|l|}{ Truck } \\
\hline $\begin{array}{l}\text { Delivery of } \\
\text { goods in cities } \\
\text { and urban } \\
\text { areas }\end{array}$ & $\begin{array}{l}\text { Class 4, 5, 6; } \\
\text { Parcel } \\
\text { delivery } \\
\text { vehicle }\end{array}$ & $\begin{array}{l}\text { Up to } 20 \text { ton } \\
\text { GVW single } \\
\text { truck, up to } \\
32 \text { ton GCW } \\
\text { combination } \\
\text { vehicle }\end{array}$ & $\begin{array}{l}\text { Small } \\
\text { delivery vans, } \\
\text { single } \\
\text { delivery truck }\end{array}$ \\
\hline $\begin{array}{l}\text { Regional } \\
\text { distribution }\end{array}$ & Class 5, 6, 7 & $\begin{array}{l}\text { Up to } 40 \text { ton } \\
\text { GCW } \\
\text { combination } \\
\text { vehicle }\end{array}$ & $\begin{array}{l}\text { Single truck } \\
(2-\text { and } 3- \\
\text { axle })\end{array}$ \\
\hline $\begin{array}{l}\text { Inter- and } \\
\text { national } \\
\text { transportation }\end{array}$ & Class 7 and 8 & $\begin{array}{l}\text { Up to } 40 \text { ton } \\
\text { GCW } \\
\text { combination } \\
\text { vehicle }\end{array}$ & \\
\hline \multicolumn{4}{|l|}{ Bus } \\
\hline $\begin{array}{l}\text { City } \\
\text { transportation }\end{array}$ & $\begin{array}{l}\text { Hotel shuttle } \\
\text { bus, city bus, } \\
\text { transit bus, } \\
\text { coach }\end{array}$ & $\begin{array}{l}\text { Taxi bus (up } \\
\text { to } 9 \text { persons), } \\
\text { city bus (up } \\
\text { to } \\
\text { persons), } \\
\text { articulated } \\
\text { bus }\end{array}$ & $\begin{array}{l}\text { Small bus (up } \\
\text { to } 12 \text { persons) }\end{array}$ \\
\hline $\begin{array}{l}\text { Regional } \\
\text { transport }\end{array}$ & $\begin{array}{l}\text { Schoolbus }(2 \\
\text { axle), transit } \\
\text { bus }\end{array}$ & $\begin{array}{l}\text { Regional } \\
\text { bus( } 2 \text { axle })\end{array}$ & $\begin{array}{l}\text { Regional bus } \\
(2 \text { axle })\end{array}$ \\
\hline $\begin{array}{l}\text { Long distance } \\
\text { travel }\end{array}$ & $\begin{array}{l}\text { Long distance } \\
\text { bus ( } 2 \text { - and } 3 \\
\text { axle), coach }\end{array}$ & $\begin{array}{lr}\text { Touring bus } \\
(2-\text { and } \\
\begin{array}{l}2- \\
\text { axle })\end{array}\end{array}$ & $\begin{array}{l}\text { Touring bus, } \\
\text { coach }\end{array}$ \\
\hline \multicolumn{4}{|l|}{ Niche } \\
\hline $\begin{array}{l}\text { Refuse } \\
\text { collection }\end{array}$ & $\begin{array}{l}\text { Garbage truck } \\
(2 \text { axle, } \quad 3 \\
\text { axle })\end{array}$ & $\begin{array}{l}\text { Garbage truck } \\
(2 \text { axle, } 3 \\
\text { axle })\end{array}$ & $\begin{array}{l}\text { Garbage truck } \\
(2 \text { axle, } 3 \\
\text { axle })\end{array}$ \\
\hline $\begin{array}{l}\text { Lift tractor in } \\
\text { ports, terminal } \\
\text { tractor }\end{array}$ & \begin{tabular}{l}
\multicolumn{2}{l}{ Single tractor, } \\
2 axle (lift \\
truck for \\
moving \\
trailers)
\end{tabular} & $\begin{array}{l}\text { Single tractor, } \\
2 \text { axle }\end{array}$ & $\begin{array}{l}\text { Single tractor, } \\
2 \text { axle }\end{array}$ \\
\hline $\begin{array}{l}\text { Mobile work } \\
\text { machines : } \\
\text { construction, } \\
\text { earth moving, } \\
\text { agriculture, } \\
\text { forestry, } \\
\text { material } \\
\text { handling, } \\
\text { municipal } \\
\text { machines }\end{array}$ & $\begin{array}{l}2-, 3-, 4-, 5- \\
\text { axle single } \\
\text { truck, dump } \\
\text { trucks } \\
\text { bulldozers, } \\
\text { crane trucks, } \\
\text { straddle } \\
\text { carrier, } \\
\text { excavator. }\end{array}$ & $\begin{array}{l}\begin{array}{l}2-,, 3-, \\
\text { axle }\end{array} \text { single } \\
\text { truck, dump } \\
\text { trucks } \\
\text { bulldozers, } \\
\text { crane trucks, } \\
\text { straddle } \\
\text { carrier, } \\
\text { excavator }\end{array}$ & \\
\hline $\begin{array}{l}\text { Others, } \\
\text { Specials }\end{array}$ & Fire engines & Fire engines & \\
\hline
\end{tabular}


The procurement process for goods vehicles in Europe shows some difference from the Americas. In Europe the basic vehicle chassis is chosen from a catalogue (a list of complete vehicle chassis configurations) of the vehicle manufacturer and various options can be added. The required body will be fixed to the chassis by the body manufacturer. In the Americas the transportation company selects a set of basic components (e.g. cab, engine, transmission, axles, options) and the vehicle manufacturer will assemble the vehicle and then the required body will be added to the chassis.

These differences in the buying process influences the demand for hybridization of the drive lines of the purchased vehicles and also the hybridization of components of the vehicles, such as electrification of the systems for the hotel loads in the cab of the vehicle and subcomponents of the engine such as air conditioning, water pumps, cooling fans, and oil pumps.

\subsection{Vehicle supply, Vehicle manufacturers}

For applications in the Medium Duty Vehicle segment most truck manufacturers are using a parallel hybrid configuration using Li-Ion battery technology.

Table 3: Various Hybrid Vehicle Systems

\begin{tabular}{|c|c|c|c|c|c|c|}
\hline \multirow{2}{*}{\multicolumn{2}{|c|}{ Truck Manufacturer }} & \multirow{3}{*}{$\begin{array}{l}\text { GWW/ Usage } \\
120 \text { Tonne } \\
\text { (Distribution) }\end{array}$} & \multirow{3}{*}{$\begin{array}{l}\text { HEV Type } \\
\text { Parallel (P2) }\end{array}$} & \multirow{3}{*}{$\begin{array}{c}\text { Energy } \\
\text { Storage } \\
\text { Li-ion } \\
\text { Batteries }\end{array}$} & \multirow{3}{*}{ 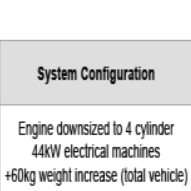 } & \multirow{3}{*}{\begin{tabular}{|c|} 
Examples \\
$\begin{array}{c}\text { Claimed FC } \\
\text { Improvemen } \\
20 \% \\
\end{array}$ \\
\end{tabular}} \\
\hline & & & & & & \\
\hline S) & $\begin{array}{l}\text { Daimler } \\
\text { (Atego BlueTec) }\end{array}$ & & & & & \\
\hline$\underset{\mathbb{Z}}{\operatorname{man}}$ & $\begin{array}{l}\text { MAN } \\
\text { (TGL 12.220) }\end{array}$ & $\begin{array}{l}120 \text { Tome } \\
\text { (Distribution) }\end{array}$ & Parallel (P2) & $\begin{array}{c}\text { Lition } \\
\text { Batteries }\end{array}$ & $\begin{array}{l}\text { Engine downsized to } 4.664 \text { cylinder } \\
2 \text { and } 6 \mathrm{WWh} \text { battery options } \\
60 \mathrm{KW} \text { electrical machine ( } 425 \mathrm{Nm} \text { ) } \\
+100 \mathrm{~kg} \text { weight (reduced payload) }\end{array}$ & $15 \%$ \\
\hline DAF & $\begin{array}{l}\text { DAF } \\
\text { (LF 45) }\end{array}$ & $\begin{array}{c}7.5 \text { Tonne } \\
\text { (Distribubion) }\end{array}$ & Parallel (P2) & $\begin{array}{l}\text { Lition } \\
\text { Batteries }\end{array}$ & $\begin{array}{l}\text { Engine downsized to } 4.5 \mathrm{~L} .4 \mathrm{cylinder} \\
44 \mathrm{~kW} \text { electrical machine ( } 42 \mathrm{Nmm}) \\
2 \mathrm{~km} \text { ful EV range (tully charged) }\end{array}$ & $30 \%$ \\
\hline IE & $\begin{array}{l}\text { Kenworth } \\
\text { (T270/ / T370) }\end{array}$ & $\begin{array}{l}11.5 / 15.0 \\
\text { Tonne } \\
\text { (Distibution) }\end{array}$ & Parallel (P1) & $\begin{array}{l}\text { Lion } \\
\text { Batteries }\end{array}$ & \multirow{2}{*}{ 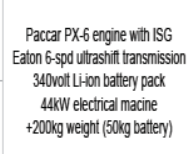 } & $20 \%$ \\
\hline 사용 & $\begin{array}{l}\text { Peterbilit } \\
\text { (330) }\end{array}$ & $\begin{array}{l}12.0 \text { Tonne } \\
\text { (Distibution) }\end{array}$ & Parallel (P1) & $\begin{array}{c}\text { Lition } \\
\text { Batteries }\end{array}$ & & $30 \%$ \\
\hline$\theta_{\text {nemo }}^{\theta}$ & $\begin{array}{l}\text { Hino } \\
\text { (Ranger) }\end{array}$ & $\begin{array}{l}13.0 \text { Tonne } \\
\text { (Distribution) }\end{array}$ & Parallel (P1) & $\begin{array}{c}\mathrm{N} \text { NMH } \\
\text { Batteries }\end{array}$ & $\begin{array}{l}\text { Hino J05D engine 4.7. } \\
\text { 36WW electrical machine (350Nm) } \\
\text { 286volt NMMH battery pack }\end{array}$ & $20 \%$ \\
\hline & \\
\hline
\end{tabular}

In the Heavy Duty Vehicle segment applications such as refuse trucks with hybrid drive systems are now coming to the market. Other niche applications are being investigated for hybridization.
Hybridization of heavy duty vehicles for long haul transportation is less valuable because of the low economic value of the reductions of the operational costs, such as reduced fuel usage, for the transport company.

The benefits of a hybrid system are dependent on the application of the vehicle and best suited to lower duty cycles and frequent acceleration/deceleration:

- Simple parallel HEV configuration appears suited to most commercial vehicles

- 'electrification' cost challenge may provide an opportunity for cheaper mechanical systems

- However, electrification of heavy duty drive systems can lead to a higher increase in system efficiency.

\subsection{Demonstrations, Pilot projects}

In the USA, Europe and Canada a number of cities use hybrid buses in the public transportation systems.

In Belgium, the public transportation company De Lijn is putting 79 hybrid buses (from midibuses up to articulated buses, see Fig. 3) into service in 2010 in different cities.

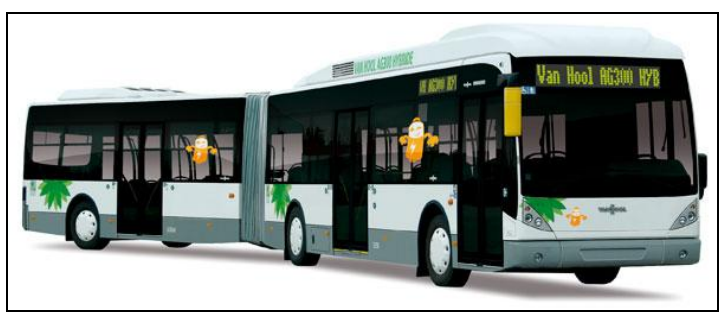

Figure 3: Hybrid diesel-electric bus (Courtesy of Van Hool)

In the USA, the National Renewable Research Laboratory (NREL) has published a number of evaluation reports on projects with hybrid buses as used in public transport in various cities [13]. More reports on medium and heavy duty vehicle field evaluations are summarized in [14].

Within the FedEx parcel delivery organization a demonstration project with 20 gasoline hybrid electric vehicles is still running in Los Angeles (USA). A first evaluation is made and results can be seen in [15]. 
UPS expanded its fleet of alternative-fuel vehicles with 200 next-generation hybrid electric vehicles (HEVs) for use in Austin, Houston, Philadelphia, Chicago, Washington, D.C., Long Island, Minneapolis and Louisville. The 200 new HEV delivery trucks are expected to reduce fuel consumption by roughly 176,000 gallons a year compared to an equivalent number of traditional diesel trucks. The hybrids should also reduce $\mathrm{CO}_{2}$ emissions by 1,786 metric tons annually. The new hybrid power system utilizes a conventional diesel engine combined with a battery pack. The small diesel recharges the battery pack and adds power when needed.

Applications of hybrid commercial goods vehicles are still in an early demonstration phase. A lot of product development still has to be done. These projects with a limited number of vehicles are executed in Europe as well as in the USA. Most projects are using LDV and MDV commercial goods vehicles.

In the USA the Hybrid Truck User Forum (HTUF) is active since the year 2000 [16]. HTUF is a national, multi-year, user-driven program to speed the commercialization of medium and heavy-duty hybrid and high-efficiency technologies.

\subsection{Market deployment and barriers}

Nowadays the transportation sector is only a marginally profitable business, especially due to the economic situation in the world during 2009 and 2010. Investments in new equipment are delayed. In the EU, sales of HDVs in 2009 were $48 \%$ less than 2008 , and during the first half of 2010 HDV sales fell $16 \%$ compared to the first half of 2009 [17].

In Europe there are indications that the transportation sector is slowly recovering and that could result in new investments by the end of 2010 .

The key issue for commercial hybrid vehicles remains the aspects of the business case: savings in fuel costs must be greater than extra purchase cost or lease cost and other operational costs of hybrids compared with conventional heavy vehicles.

Other aspects besides economics also play a significant role, such as risk aversion to adopting new technology and concern for required changes to driver habits.

Market studies predict a future market share for Hybrid Light Duty and Medium Duty Trucks in Europe and the Americas:

- For light duty trucks hybrid diesel will gain market share, while diesel ICEs share will fall.

- For medium duty trucks, diesel powertrains will remain the most prevalent technology, with a limited tendency towards hybrid.

- For heavy duty trucks, ICE diesel will remain the most prevalent technology.

In the case of hybrid buses, we can see more and more demonstration projects on city buses but some kind of government support is still needed to make the demonstration projects economically possible.

Because the types of applications in mobile work machines are even more diverse than those in trucks and buses, we will focus on this topic more in detail in the next section.

\section{$5 \quad$ Mobile work machines}

\subsection{Background}

Work machines are mobile (mainly wheeled or tracked) machines targeted for a defined task in off-road conditions. Traditionally work machines are divided by the application area. The biggest area is construction machines or earth-moving machines including all kinds of loaders, dumpers, excavators, land rollers, bulldozers, etc. Transportation of goods or material handling equipment includes forklifts, Automatic Guided Vehicles, mobile cranes, Rubber Tyred Gantry Cranes, straddle carriers, etc. The municipal or janitorial machines include different types of gardening and cleaning machines which are often also targeted for on-road operations. Another big group is that of tractors and other agricultural (and forestry) machines. It seems that today's trend is specialization and work machines are more and more designed for niche applications.

As with the application areas, the vehicle peak power requirements also vary a lot. Small loaders 
and utility vehicles start from $10 \mathrm{~kW}$ peak power while the gigantic dumpers have peak power capability in excess of $3 \mathrm{MW}$.

\subsection{Trends in the mobile work machine industry}

From the technology point of view, the clear trend is to improve the productivity, operator comfort and machine safety by improving the smooth control of the machine traction and actuators. Additionally the increasing automation level provides different measurements such as load sensing, actuator positioning, etc. and enhanced support for task execution and data transfer. The most advanced commercial applications include also autonomous driving and manipulation. Good example is Automine ${ }^{\mathrm{TM}}$ [19], Sandvik's automatic loading and hauling system for underground mines.

Machine types are evolving in two opposite directions. The need for improving productivity promotes more and more task specific machines while multipurpose machines are favored by incity construction sites with one-man contractors.

From the market point of view, the megatrend is for increased rental and lease business, which is driven both from financial and taxation reasons. This is especially common for construction machines due to the "bid and build" project nature of the construction industry [18].

\subsection{Drivers towards hybridization}

Drivers towards heavy duty hybridization are similar to the drivers behind hybridization of passenger cars. These drivers include increasing oil price and tightening emission regulations, both of which require higher system efficiency. Requirement of smooth continuously variable transmission and actuator control are also promoting the use of electric transmissions. Existing electric machines have proved that electric transmission needs less maintenance compared to traditional ones. Together with better efficiency, this decreases the lifetime costs remarkably. A "green image", which is important in consumer market, is a plus in the work machine market but very few customers - mainly in the municipal machine area - are willing to pay extra for this. Free placement of system components connected with flexible cables is important in complex structured machines. However, this can also be solved with hydrostatic transmissions.
The opposing drivers are also more or less the same as in the automotive market. Hybridization increases the system complexity and price. The higher purchasing price will be approved only if the salesman can convince the buyer that the full lifetime cost will be lower. From the technology point of view the "not yet ready battery technology" and the lack of power electronics and electric motors fulfilling the automotive requirements are also retarding the development. Additionally, big technological steps are naturally resisted in the very conservative conventional application areas. A summary of drivers is shown in Fig. 4.

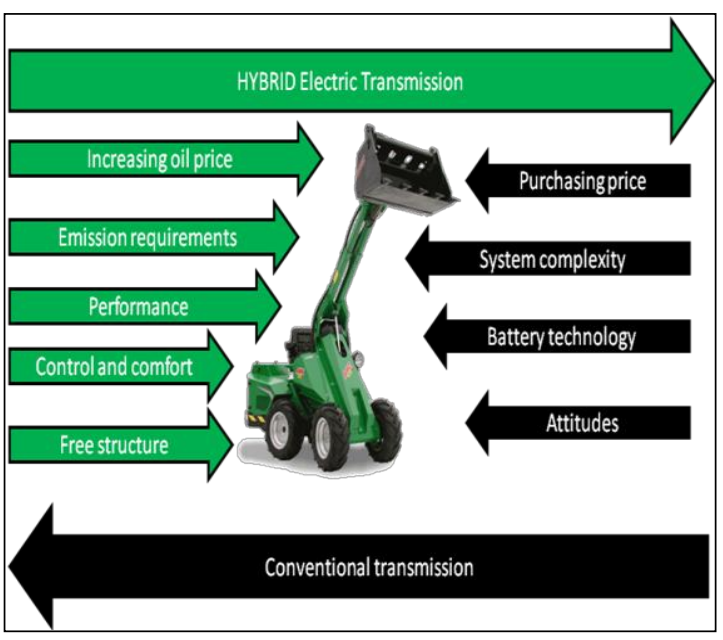

Figure 4. Drivers towards Hybrid Electric transmission

\subsection{Differences comparing to on-road vehicles}

From the hybridization point of view there are several differences between road vehicles and work machines. Perhaps the biggest is the huge variety in the duty cycle. While road vehicles share similar duty cycles, for work machines, each machine type has its own unique duty cycle. Work machines are also mainly in professional use and thus the yearly operating hours are high. A comparison between work machines, cars and onroad heavy duty vehicles appears in Table 5. 
Table 5: Comparison of cars, heavy duty road vehicles and work machines

\begin{tabular}{|l|l|l|l|}
\hline & Car & HD & Work \\
\hline $\begin{array}{l}\text { Operating } \\
\text { hours }\end{array}$ & $\sim 250 \mathrm{~h} / \mathrm{a}$ & $5000 \mathrm{~h} / \mathrm{a}$ & $5000 \mathrm{~h} / \mathrm{a}$ \\
\hline Power & $\sim 100 \mathrm{~kW}$ & $100-400 \mathrm{~kW}$ & $10 \mathrm{~kW}-3 \mathrm{MW}$ \\
\hline $\begin{array}{l}\text { Average } \\
\text { operating } \\
\text { power }\end{array}$ & $20 \%$ of max. & $\begin{array}{l}40 \% \text { of } \\
\text { max. }\end{array}$ & $\begin{array}{l}50-80 \% \\
\text { max. }\end{array}$ \\
\hline $\begin{array}{l}\text { Cycle } \\
\text { city } \\
\text { highway }\end{array}$ & $\begin{array}{l}\text { city } \\
\text { highway }\end{array}$ & $\begin{array}{l}\text { application } \\
\text { specific }\end{array}$ \\
\hline Speed & $0-200 \mathrm{~km} / \mathrm{h}$ & $0-100 \mathrm{~km} / \mathrm{h}$ & $0-40 \mathrm{~km} / \mathrm{h}$ \\
\hline $\begin{array}{l}\text { Max. } \\
\text { traction } \\
\text { force/ma } \\
\text { x. speed } \\
\text { traction } \\
\text { force }\end{array}$ & 5 & 20 & $10-30$ \\
\hline $\begin{array}{l}\text { Manufact } \\
\text { series }\end{array}$ & mass & mass & $\begin{array}{l}\text { small } \\
(10- \\
1000 / \text { year })\end{array}$ \\
\hline $\begin{array}{l}\text { Power } \\
\text { trans- } \\
\text { mission }\end{array}$ & Mechanical \\
\hline $\begin{array}{l}\text { Power } \\
\text { regenera- } \\
\text { tion }\end{array}$ & $\begin{array}{l}\text { city yes } \\
\text { highway not } \\
\text { really }\end{array}$ & $\begin{array}{l}\text { Mechanical } \\
\text { highway not } \\
\text { really }\end{array}$ & $\begin{array}{l}\text { mechanical, } \\
\text { hydrostatic, } \\
\text { hydrodynamic }\end{array}$ \\
\hline $\begin{array}{l}\text { Practical } \\
\text { lifetime }\end{array}$ & 9 years & 8 years & $\begin{array}{l}\text { Depending on } \\
\text { application }\end{array}$ \\
\hline $\begin{array}{l}\text { Customer } \\
\text { will pay } \\
\text { for imago } \\
\text { issues }\end{array}$ & yes & no & no \\
\hline
\end{tabular}

\subsection{Existing commercial (H)EV work machines}

Among existing work machines, size really matters. Machines with electric power transmission are found from the smallest and the biggest classes of machines. In low power machines, battery operation is technically and commercially feasible. Especially in applications where the environment requires zero emissions or low noise level, electric vehicles have a market. The largest application with no doubt is indoor forklifts both human operated and Automatic Guided Vehicles. Small utility vehicles used in janitorial and gardening services are also available in battery powered versions.

In the mid-power class from 50-200 $\mathrm{kW}$ the amount of commercial $(\mathrm{H}) \mathrm{EVs}$ is small but when the work machine power needs increase, this increases the attractiveness of electric transmission. The biggest machines are more often driven electrically. Rail machines such as different types of cranes are naturally electric due to the easy power supply by cable or trolley but also freely navigating machines such as gigantic dump trucks (see Fig. 5), straddle carriers and even LHDs (Load Haul Dump machines) are often electrically driven.

Big size and power provides a very good starting point for (diesel) electric power train. The reason for this is that in high power systems, energy efficiency is more crucial than for low power systems. Also, in the megawatt-class power range, the control of an electric transmission is much easier than control of a diesel mechanical system. Finally, in diesel electric systems the big size allows space for the needed additional hardware. In fact, electric transmission for high power work machines is so successful that there are almost no traditional power train systems with megawatt power capability.

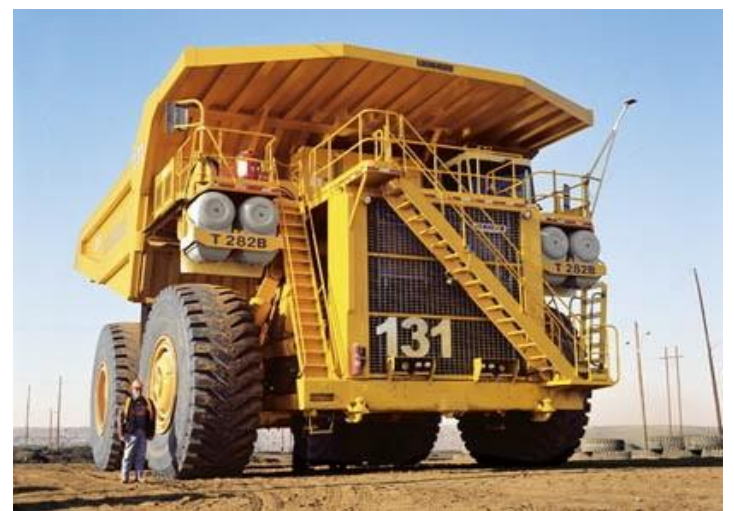

Figure 5 : Liebherr T282B Dump Truck

Dump truck and straddle carrier are both diesel electric. In a diesel electric dump truck, the diesel electric system saves fuel and reduces emissions due to the ability to operate the diesel at a constant speed. Electric drives provide better controllability, the possibility to use off-vehicle electric supply and electric braking with regeneration. Also the maintenance costs are smaller for electric powertrains than with a traditional machine with mechanical transmission.

Commercial work machines with hybrid transmission are difficult to find. As mentioned, diesel-electric and battery electric machines are available but hybrids are yet very rare. One of the first is Cargotec's hybrid straddle carrier which was presented in June 2008. It has a series hybrid driveline with super capacitor buffering for high power peaks during deceleration and lifting the load down. 


\section{Conclusion}

Advanced powertrain technology for heavy vehicles includes full electric, hybrid electric, hybrid hydraulic and plug-in hybrid electric systems. For on-road vehicles, the hybrid electric powertrain is the most common, but all of the above-mentioned powertrain technologies have some market presence. The use and advantage that each powertrain technology has to offer differs by heavy vehicle size category and application. For on-road vehicles, hybrid powertrains are best suited to duty cycles with frequent acceleration/deceleration to reach higher system efficiencies. For mobile work machines there is a huge variety in duty cycles, but also here we can see a growing interest in the electrification of powertrains. But besides the duty cycle a lot of other aspects influence the final choice of the powertrain: full lifetime cost (purchasing price, maintenance cost, fuel consumption, etc.), performance, driver comfort, risk aversion to adopt new technology, environmental aspects, etc. The procurement process of vehicles follows the principles of industrial investment rules and in the current economic situation investments are delayed.

However, the potential benefits (technological, economical and ecological) of the electrification of powertrains in heavy-duty vehicles must be fully explored. Therefore, a continuous effort on research \& development \& demonstration level is crucial to collect and share the necessary data to be able to make grounded decisions based on objective data. As part of the International Energy Agency Implementing Agreement "Hybrid \& Electric Vehicles", Annex XII on "Heavy-duty hybrid vehicles" has embarked on this task to collect and share relevant information on the latest technical and market developments in "electrified" trucks, buses and mobile work machines.

\section{Acknowledgments}

The authors would like to thank all supporting contributions to Annex XII on "Heavy-Duty Hybrid Vehicles" of the Hybrid and Electric Vehicles Implementing Agreement of the International Energy Agency.

These include David Howell of the U.S. Department of Energy, Natural Resources Canada, Agency NL, Tekes, the Belgian Federal Government and the Swiss Federal Office of Energy. The authors also gratefully acknowledge the contributions of Ahmad Pesaran, Charles Thibodeau, Gary Murray, Fabian Allard, Carol Burelle, Stefan Smets, Dick Appels, Alex Naef, Teemu Lehmuspelto and Martijn van Walwijk. 


\section{References}

[1] J. Ward and S. Davis. (2009). "2008 Vehicle Technologies Market Report." U.S. Department of Energy Technical Report. [Online]. Available: www.nrel.gov/docs/fy09osti/46018.pdf.

[2] Business Wire, (2006). "Oshkosh Truck Unveils Fuel Saving Hybrid Drive Refuse Vehicle." Business Wire. November 2006. [Online]. Available: www.allbusiness.com/.

[3] N. Shachtman. (2006). "Hybrid Truck's Katrina Duty." Noah Shachtman's Blog, posted March 29, 2006. [Online]. Available: www.noahshachtman.com/archives/002277.html. [Accessed: Aug. 12, 2010].

[4] Northeast Advanced Vehicle Consortium, M.J. Bradley \& Associates, West Virginia University. (2000). "Hybrid-Electric Drive Heavy-Duty Vehicle Testing Project: Final Emissions Report." NAVC Technical Report. [Online]. Available: www.navc.org/Navc9837.pdf. [Accessed: Aug. 12, 2010].

[5] R. Barnitt, K. Chandler. (2006). "New York City Transit (NYCT) Hybrid (125 Order) and CNG Transit Buses." National Renewable Energy Laboratory Technical Report NREL/TP-540-40125.

[6] M. Lammert. (December 2009). "Twelve-Month Evaluation of UPS Diesel Hybrid Electric Delivery Vans". National Renewable Energy Laboratory Technical Report NREL/TP-540-44134.

[7] R. Hayes, A. Williams, J. Ireland, and K Walkowicz. (2006). "King County Metro Transit: Allison Hybrid Electric Transit Bus Laboratory Testing". NREL/TP-540-39996. [Online]. Available: www.nrel.gov/vehiclesandfuels/fleettest/pdfs/39996.pd f. [Accessed: Aug. 12, 2010].

[8] S. Blanco. (2007). "Odyne, Dueco will build PHEV aerial lift truck." Autoblog Green blog, posted May 7, 2007. [Online]. Available: green.autoblog.com [Accessed: Aug. 12, 2010].

[9] CalCars. (2007). "New PHEVs: Ford Escape/Eaton Utility Truck/Army/Mercedes by Siemens/Sprinter Expansion." News Archive, posted Aug. 23, 2007. [Online]. Available: www.calcars.org/calcarsnews/831.html. [Accessed: Aug. 12, 2010].

[10] Eaton Corporation. (2006). "Hydraulic Hybrids: The Most Efficient Lowest Cost Hybrids." Brochure.
[Online]. Available: www.eaton.com/epa/420f06043.pdf [Accessed: Aug. 12, 2010].

[11] Bosch. (2008). Press releases for the 62nd IAA Commercial Vehicles Conference. [Online]. Available: http://www.bosch-presse.de/ [Accessed: Aug. 12, 2010].

[12] Wikipedia. (2010). "Truck classification". Wikipedia article. [Online]. Available: www.en.wikipedia.org/wiki/Truck_classification [Accessed: Aug. 12, 2010].

[13] Publications database of the National Renewable Energy Laboratory. [Online]. Available: www.nrel.gov/publications [Available: Aug. 12, 2010]

[14] K. Walkowicz. (2010). "Medium and Heavy-Duty Vehicle Field Evaluations." 2010 US Department of Energy Annual Merit Review. [Online]. Available: www.eere.energy.gov/ [Accessed: Aug. 12, 2010].

[15] R. Barnitt. (May 2010). "FedEx Gasoline Hybrid Electric Delivery Truck Evaluation: 6-Month Interim Report". National Renewable Energy Laboratory Technical Report NREL/TP-540-47693. [Online]. Available: www.nrel.gov/docs/fy10osti/47693.pdf. [Accessed: Aug. 12, 2010]

[16] Website of the Hybrid Truck Users Forum. [Online]. Available: www.calstart.org/Projects/HybridTruck-Users-Forum.aspx [Accessed: Aug. 12, 2010].

[17] European Automobile Manufacturers Association (ACEA). (2010). "EU Economic Report." ACEA Report. June 2010. [Online]. Available: www .acea.be/images/uploads/files/20100709_ER_100 6_2010_II_Q1.pdf. [Accessed: Aug. 12, 2010].

[18] Freedonia Group. (2009). "Introduction - world heavy construction equipment to 2009, market study." [Online]. Available: www.freedoniagroup.com/WorldHeavy-Construction-Equipment.html. [Accessed: Aug. $12,2010]$.

[19] Woof, M., Technology for Underground Loading and Hauling Systems Offers Exciting Prospects, Engineering and Mining Journal, April 2005.

[20] "A123 to Power Plug-in Hybrid Trouble Truck for Eaton Corporation." Green Car Congress. May 11, $2010 . \quad$ [Online]. Available: http://www.greencarcongress.com/ [Accessed: Aug. 19, 2010]. 


\section{Authors}

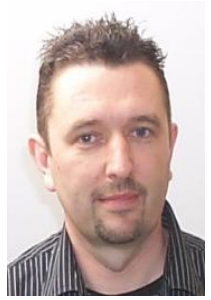

Carlo Mol graduated as engineer on electricity-electronics. $\mathrm{He}$ is working at VITO as project developer and researcher on the integration of electric vehicles in smart grids and takes part in the IEA IA on Hybrid and Electric Vehicles as member of the ExCo and as Operating Agent of Annex XII on Heavy-duty hybrid vehicles. Previously he worked 7 years in the Flemish Competence Centre for the vehicle industry. One of the main research topics was clean powertrains.

Michael O'Keefe is a senior researcher with the National Renewable Energy Laboratory working in the Center for Transportation Technologies and Systems. Michael has worked on various advanced hybrid electric vehicle projects with the commercial truck industry and helped develop NREL's Advanced Vehicle Simulator or ADVISOR software. Michael currently supports DOE's hybrid electric and plug-in hybrid electric vehicle efforts in the area of power electronics.
Arie Brouwer is educated as an automotive engineer and has also master degrees in industrial engineering and business administration. He has 15 years experience in product planning, product development and management accounting with truck manufacturer DAF Trucks in the

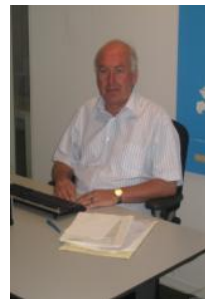
Netherlands and another 16 years experience in the transportation department of the Netherlands Agency for Innovation and Sustainability, an agency of the ministry of economic affairs in the Netherlands. Since May 1, 2010, he is retired and work as a consultant.

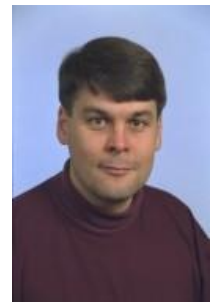

Jussi Suomela received the M.Sc., Lic.Sc., and D.Sc. degrees from Helsinki University of Technology (TKK), Espoo, Finland, in 1992, 2001 and 2004, respectively. In the start of 2010 TKK became a part of new Aalto University. Suomela has worked in the University since 1991 in various positions. His main research areas are hybrid electric transmission in off-road mobile machines and field and service robotics. At the moment Suomela is professor of automation technology. 